\title{
Firm Size Distribution and the Effects of Ownership Type
}

\section{- Marek Csabay, Beata Steblikova}

\begin{abstract}
Size distribution is generally accepted as an important characteristic of business structure, one which impacts on competitiveness, with firm size often regarded as the key determinant of entrepreneurial innovativeness. This article describes the size distribution of enterprises taken from a statistical set of Slovak business entities with a special focus on the relation between size and ownership of the businesses. A change in the probability firm size distribution is an undisputable indicator of a change in the business structure. This article seeks to create an eventual starting point for better policymaking in Slovakia, a country which bases its competitiveness primarily on large and medium-sized foreign investments. The authors' main objective is to determine the size distribution type of the firms. The Anderson-Darling and Kolmogorov-Smirnov tests were used to determine if the dataset has been taken from a population with a specific distribution. Among the main results with regard to Slovak business structure, a statistically significant dependence was shown between the ownership type and the size type of SMEs. The authors confirmed the Pareto, Power and Generalized Gamma distributions as appropriate probability distributions of firm sizes. The probability distribution of SMEs in general as well as according to individual ownership type shows a Lévy distribution. The authors used the environment of the $\mathrm{R}$ programming language along with the software EasyFit.
\end{abstract}

Keywords: business structure, size distribution, competitiveness, industrial organization, Slovakia JEL Classification: L11

Received: May, 2020

1st Revision: October, 2020

Accepted: November, 2020

\section{INTRODUCTION}

Small and medium-sized enterprises (SMEs) account for $99.9 \%$ of all entrepreneurs within the Slovak business structure (Table 1), with further data showing that these firms provide employment opportunities to almost three-quarters $(73 \%)$ of the active workforce and contribute more than half $(55 \%)$ of added value, while almost $97 \%$ of Slovak SMEs are micro-enterprises employing less than 10 employees (SBA, 2019a). Large enterprises, on the other hand, form just $0.1 \%$ of all registered business entities (SBA, 2019b). In 2018, only 679 large enterprises were represented out of a grand total of 560,521 active business entities, a figure including legal persons as well as self-employed persons, freelancers and independent farmers. Nevertheless, the impact of 
large enterprises with more than 250 employees on the creation of gross domestic product can be described by the observation in the Slovak edition of the economic monthly Forbes that 50 companies create $60 \%$ of Slovak GDP (Matijek, 2018), a with a similar figure mentioned in other sources. Two other reports from the Slovak Ministry of Economy focusing on foreign trade and exports in particular state that "more than a half of Slovak exports come from the 50 largest exporters" (Ministry of Economy, 2017), and "more than 60\% of exports come from large companies" (Ministry of Economy, 2020).

Tab. 1 - Active Business Entities (at the end of 2018). Source: Slovak Business Agency based on data from the Statistical Office of the Slovak Republic

\begin{tabular}{|c|c|c|c|c|c|c|}
\hline \multirow{2}{*}{$\begin{array}{c}\text { Size Categories / } \\
\text { Legal Forms }\end{array}$} & \multirow{2}{*}{$\begin{array}{c}\text { Legal } \\
\text { persons }\end{array}$} & \multirow{2}{*}{$\begin{array}{c}\text { Self- } \\
\text { employed } \\
\text { persons }\end{array}$} & \multirow{2}{*}{$\begin{array}{l}\text { Free pro- } \\
\text { fessions }\end{array}$} & \multirow{2}{*}{$\begin{array}{l}\text { Independ- } \\
\text { ent farmers }\end{array}$} & \multicolumn{2}{|c|}{ Total } \\
\hline & & & & & Count & Share $(\%)$ \\
\hline Microbusiness & 213,462 & 302,677 & 22,703 & 3,683 & 542,525 & $96.8 \%$ \\
\hline Small Business & 13,062 & 1,236 & 20 & 10 & 14,328 & $2.6 \%$ \\
\hline $\begin{array}{l}\text { Medium Busi- } \\
\text { ness }\end{array}$ & 2,940 & 47 & 1 & 0 & 2,988 & $0.5 \%$ \\
\hline Large Business & 679 & 1 & 0 & 0 & 680 & $0.1 \%$ \\
\hline SMEs Sub-total & 229,464 & 303,960 & 22,724 & 3,693 & 559,841 & $99.9 \%$ \\
\hline Total & 230,143 & 303,961 & 22,724 & 3,693 & 560,521 & $100.0 \%$ \\
\hline
\end{tabular}

Based on the information above, it is clear that most descriptions from several points of view trend towards the conclusion (relevant for policy-making) that in the Slovak business structure a relatively large share on a respective indicator is represented by only a few companies. In most cases, these conclusions go hand in hand with the assumption that large (and mostly foreign-owned) companies dominate the Slovak economy despite the low incidence of these firms. Empirical links to competitiveness are mirrored, e.g. in Slovakia's exports, however, this may be also identified theoretically i. a. through innovations, for which firm size represents a key determinant (Trang \& Nam, 2020), as large firms will be under certain circumstances more effective than small firms in generating technological progress based on the Schumpeterian firm-size hypothesis (Link \& Scott, 2018; An \& Kim, 2019). The size of a firm determines its position vis-à-vis competitors; hence, firm size distribution and competition are closely related. It is thus desirable to analyze these factors in conjunction (Babutsidze, 2016). However, the identification of the firm size probability distribution for the complete dataset of Slovak companies has to our best knowledge not been studied. In contrast, this distribution has been the subject of lively academic discussion in other countries, a summary of which will be presented in the following section of this article. We seek to contribute to this international debate and thus provide a basis for comparative analysis. A change in the probability distribution may prove to be a clear indicator of a potential and substantial alteration in the structure of companies which might easily take place in the course of the next few years as a result of measures taken in relation to Covid-19 pandemic. This article presents results based on data before the crisis which provide a timely snapshot of entrepreneurial structure as a comparative base for observations during and after the course of the events. 
The paper is structured into six sections. This brief introduction is followed by the second section providing a literature overview and theoretical background related to firm size distribution. The third section introduces the methodology and the data found in our research. The fourth section presents our results, followed by a discussion and conclusions in the last two sections.

\section{THEORETICAL BACKGROUND}

Generally no business is planned from the beginning as a large one. Perhaps more precisely, the maximum size of an enterprise cannot be projected as it is being established, thus we may assume that the size of the companies is a result of their subsequent growth. Growth is a result of the selection of successful firms to imitate as well as the firm's own idiosyncratic productivity improvements (Luttmer, 2007). Various rates of growth along with different lengths of time after the entry into the market greatly influence the size of a particular company at a given moment. Technological changes also do not benefit all potential entrepreneurs equally (Poschke, 2018). The size distribution of businesses has been subject to economic analysis for almost a century. Economic phenomena such as economic growth, international trade elasticities, and the sources of aggregate fluctuations are among others affected by the firm size distribution (Kondo et al., 2018). From the opposite perspective, development itself is associated with systematic changes in firm size distribution. Since modern economies are dominated by large firms, idiosyncratic shocks to these key firms can lead to significant aggregate shocks for all (Gabaix, 2011).

One of the most important strands in the literature on market structure begins with Gibrat's law of proportional effect dating back to 1930s. Gibrat's law basically states that the proportional rate of growth of a firm is independent of its absolute size at the beginning of the examined period; in other words, the probability of a given proportionate change in size during a specified period is the same for all firms in a given industry. It is only natural to expect that firms in each size-class have the same chance on average of increasing or decreasing in size in proportion to their present size (Simon \& Bonini, 1958). It seems that there are good reasons to expect small firms to grow faster than large firms (Stam, 2010). An overview of the empirical literature related to the testing of Gibrat's law has been collected by Santarelli et al. (2006). The firm size distribution theory has been affected by the work of Jacob Viner (1932), becoming one solution to an extremum problem: allocating production over firms so as to minimize total cost.

However, there is no obvious rationale for positing any general relationship between a firm's size and its expected growth rate, nor is there any reason to expect the size distribution of firms to take any particular form for the general run of industries. Most authors claim that the distribution will be skewed, but do not specify the extent of skewness, nor the particular form which the size distribution might take (Sutton, 1997). Montebruno et al. (2019) state that a mere search in a current edition of the scientific journal Physica A (home of possibly the most extensive scientific discourse on size distribution) dedicated to statistical mechanics brings hundreds of results for the Pareto distribution, Lognormal, Zipf's and Gibrat's law. This is proof that the lively debate on this matter has not reached a clear outcome. Montebruno et al. (2019) stress that it is rather difficult to distinguish the power and Pareto models. Similarly, Kondo et al. (2018) state that the existing literature is mixed regarding the nature of the best-fitting size distribution model. Simon 
\& Bonini (1958) in one of the earlier works on this topic indicated that the size distribution of firms is almost always highly skewed, and that its upper tail resembles the Pareto distribution. Axtell (2001), on the other hand, postulates that beginning with Gibrat, firm sizes have often been described by lognormal distribution. In industrial countries, usually small numbers of large firms coexist alongside larger numbers of smaller firms, their distributions are skew to the right, meaning that much of the probability mass lies right on the modal value - thus, the modal firm size is smaller than the median size, which, in turn, is smaller than the mean (ibid.). Axtell (2001, 2006) himself speaks rather of the Zipf distribution in the case of U.S. firms. Bottazzi et al. (2015) tested the reliability of Zipf's Law estimators. Power laws in economics have been comprehensively explained, e.g. by Gabaix $(2009,2016)$.

As far back as the mentioned Gibrat (1931), researchers have related the shape of the observed size distribution to the models of firm entry, random growth and exit (Luttmer, 2007). The age of the firms is indeed a factor regarded by the literature dedicated to firm size distribution. The novelty of the approach by Coad (2010) is the application of the mathematical model to the firm age and growth, and the resultant firm size distribution. His model takes a different approach from other models of the Pareto firm size distribution by taking the age distribution as the point of departure, instead of focusing on entry, exit and survival rates. Geerolf (2017) recently tried to prove that Pareto upper tails in firm size distribution may arise from production functions in some cases, meaning that they can be generated endogenously and not only through an assumption that some other variable is distributed according to the Pareto distribution.

Portuguese firms' size distribution has been in focus of Pascoal et al. (2016), who fitted three distributions to their data: the lognormal, the Pareto (and as a particular case Zipf) and the Simplified Canonical Law (SCL). When applying these approaches to Portuguese firms' data, they analyzed if the evolution of estimated parameters in both lognormal, power, and SCL were in accordance with the known existence of a recession period after 2008. This is confirmed for sales, but not for assets, leading to the conclusion that the first variable is the best proxy for the firm size.

Angelini \& Generale (2008) elaborated more on the sample of Italian firms in order to verify the role of finance, which is just one of the firm growth determinants. However, they confirmed the negative link between financial constraints and firm size: firms that declared to be constrained were on average smaller than those that did not, and their firm size distribution was more skewed to the right. The connection between financial constraints and firm size distribution has been as well examined by Meisenzahl (2016) or Yuan et al. (2016). A completely different perspective on the respective topic is presented by Gourio \& Roys (2014), examining the relationship between size-dependent regulations and firm size distribution. Rotundo \& Scozzari (2009) state that the weak form of Gibrat's law has been shown to be compatible with power law under further hypotheses, e. g. when the Gibrat's law is combined with an entry process, the Lévy distribution for firms' size can be obtained.

Most of the above-mentioned papers focusing on firm size distribution analyze the structures of Western industrial economies (beyond those already mentioned e. g. Garicano et al., 2016; Gaffeo et al., 2012) or large economies such as China (Torsten \& Shuanping, 2016; Peng \& Xia, 2016; Zou, 2019 and others). One of the few aiming at the region of Central and Eastern 
Europe (CEE) is the recent study by Lyócsa \& Výrost (2018) testing the firm size distribution in 10 emerging economies. Similar to the results of previous studies that examined developed and much larger economies, their results indicate that power-law firm size distributions are plausible at the country and industry levels of most CEE countries. They also tested how the lognormal distribution fitted their data and found that at both country and industry levels it fitted even better than the power-law distribution.

\section{DATA AND METHODOLOGY}

The aim of our research is related to the analysis of the business structure from the firm size distribution perspective. We seek to identify the kind of probability size distribution on the empirical dataset of Slovak business entities and to verify the adjustment of the data to the probability distribution functions known from the essential literature on this topic. Special attention will be naturally paid to SMEs due to their prevalence in the business structure. The identification of the kind of dependence between the ownership and size will be a matter of our interest, too, as well as the determination of a potential causality between the number of large enterprises and SMEs. From these two latter perspectives, the authors are unaware of a previous research in this field, hoping thus to present original outcomes of their research.

In this paper, we proceed with further research on a data set, previously analyzed from the perspective of ownership structure, that includes anonymized information about business entities on the LAU level of territorial administration (formerly also known as NUTS level 4), i. e. 79 districts of the Slovak Republic. All data have been sourced from the statistical register of organizations in mid-2018, which accounted for 569,742 entities at that time. Here is meant the total number of registered entities. The difference to the respective count presented in Table 1 results from the fact that Table 1 counts active business entities. Every district data comprises an absolute count of active businesses, both legal entities and natural persons - entrepreneurs, structured from the perspective of their size with regard to the number of employees, form of their ownership and subject of their main economic activity based on the standard classification.

The type of ownership of the enterprises in the analyzed dataset is divided into 8 standard types as used by the Statistical Office of the Slovak Republic - international with a prevailing public sector (marked as DV1), private inland (DV2), cooperative (DV3), state (DV4), municipal including other self-governing (DV5), ownership by associations, political parties and churches (DV6), foreign (DV7), and international with a prevailing private sector (DV8). From the perspective of the enterprise size classification, the examined dataset contained stratification of enterprises based on the number of employees only, deviating thus from the standard EU classification requiring besides the number of employees also an inclusion of selected financial indicators. The EU applies the size categories of enterprises based on the European Commission Recommendation No. 2003/361/EC concerning the definition of micro, small and medium-sized enterprises and Regulation No. 651/2014, Annex I. Based on these, the following three criteria are considered in the definition of SMEs: number of employees, annual turnover and/or annual balance sheet total.

The staff headcount aspect of the EU methodology divides enterprises into 3 SME groups: 
micro-enterprises with less 10 employees, small enterprises with less than 50 employees and medium enterprises with less than 250 employees. Implicitly this classification regards any enterprise with 250 and more employees as a large one. Compared to the EU classification however, a more detailed stratification of companies is present in our dataset, dividing them from the size perspective into 7 groups (size types) that would eventually fulfill the EU criterion based on the number of employees: 0 employees (marked as VT1), 1-4 employees (VT2), 5-9 employees (VT3), 10-24 employees (VT4), 25-49 employees (VT5), 50-149 employees (VT6) and 150-249 employees (VT7). Large enterprises are from this perspective also subdivided into 4 further groups of 250-499 employees (VT8), 500-999 employees (VT9), 1,000-1,999 employees (VT10) and 2,000 and more employees (VT11) with the latter three accounting for less than a half of all large companies. An important remark in this context is that a significant number of companies are statistically registered in a separate group with the undetermined number of employees (VT99) and have been thus excluded from our research. The explanation for this is quite simple as there is no obligation for the Slovak companies to report the number of employees to the Statistical Office and the available dataset is obviously not interlinked with the data from the Social Insurance Agency registering all employees for the purposes of social insurance.

Our primary goal was to determine the distribution of firm sizes in Slovakia. The authors chose a suitable distribution model from 55 continuous distributions in EasyFit software. The results for specified probability distributions known from the literature review - lognormal, power, Pareto, Lévy, three parameter generalized gamma (lognormal is its special case) are presented. All the mentioned distributions have heavy tails. Based on Bryson (1974), heavy-tailed distributions are probability distributions whose tails are not exponentially bounded. Heavy tail means that there is a larger probability of getting very large values. In our case, this means the existence of companies with a very large number of employees. Not all moments exist for these distributions. It also means that the central limit theorem no longer holds (Wolfram, 2020). The mean would be very misleading, if it exists at all. The Lévy distribution has infinite mean. The sample mean of heavytailed distributions usually underestimates the population mean. The sample standard deviation is very large, for some distributions it is infinity. For the Lévy distribution variance, skewness, and kurtosis do not exist. In our case, this means that the average size of the enterprise and its standard deviation are not suitable characteristics. In addition to the mentioned features of the Lévy's distribution, one of its properties is interesting for studying the division of enterprises by size. The Lévy distribution has one parameter - scale parameter sigma $\sigma$. The mode of the density function is at the $\sigma / 3$ point. As the value of the parameter sigma $\sigma$ increases, the distribution becomes flatter for the lowest values and symmetrical for very high values (Ahsanullah \& Nevzorov, 2019). The density function is concave upward, then downward, then upward again with inflection points at $(1 / 3 \pm \sqrt{ } 10 / 15) \sigma$.

EasyFit supports the parameters estimation of the distributions. We used two goodness of fit tests: Kolmogorov-Smirnov and Anderson-Darling. The Anderson-Darling test gives more weight to the tails than does the Kolmogorov-Smirnov test to determine the distribution type (Rimmer \& Nolan, 2005). In the second step, we verified the dependence between the ownership type and the size type of SMEs using the Chi-square test of independence (Rosenthal, 2011). The p value for Chi-square test statistics is calculated using simulations in the R computing environment. 


\section{RESULTS}

Before we proceed into a deeper analysis of the size distribution of Slovak businesses, we shall do some basic description of the data characterizing respective size types of registered businesses combined with their ownership type. As already mentioned earlier, a significant number of businesses - almost $44 \%$ of the entities in our dataset - have no indication of the employees count. On the other hand, the group of those with an indicated number of employees is statistically more than representative. In the statistical sample of 319,985 companies that reported the number of employees and will be discussed within this article, there are 319,128 SMEs and 857 large enterprises.

By far the most numerous size types naturally consist of companies with no employees followed by the group with $1-4$ employees. These two size types represent $86.7 \%$ of all SMEs and $86.5 \%$ of all companies in the statistical sample. Their high share roughly reflects the structure in most, if not all economies. Similarly reflecting a markedly visible trend, the counts of registered units are continuously declining with the rising number of employees in respective size types as can be seen in the last column of Table 2. Thus, the group of largest companies (size type VT11 with 2,000 and more employees) has the fewest membership counting only 55 business entities. However, their impact on the economy shall be regarded as substantial.

When taking into account the other statistical attribute - the kind of ownership - the picture is, however, not that straightforward. Naturally, a dominating number of companies are in private inland (i. e. domestic) ownership, whose size structure follows the above-mentioned tendency of indirect correlation between the size type based on number of employees and their count in the respective size type group both in absolute as well as in relative terms.

On the other hand, state ownership follows a sort of direct correlation - the larger the company size, the larger the count of state owned enterprises up the size type VT6 (50-149 employees); beyond that, from the size type VT7 onwards, even with a sudden contraction from 269 companies in VT6 to 65 companies VT7 and a continuous decrease in the number of large companies in absolute terms towards the larger size types, the share of the state ownership increases in relative terms.

Tab. 2 - Overview of the Business Structure from the Perspective of Size and Ownership. Source: authors based on data from the Register of Organizations of the Statistical Office of the Slovak Republic

\begin{tabular}{|l|l|l|l|l|l|l|l|l|l|}
\hline $\begin{array}{l}\text { Ownership } \\
\text { type /Size } \\
\text { type }\end{array}$ & DV1 & DV2 & DV3 & DV4 & DV5 & DV6 & DV7 & DV8 & Total \\
\hline $\begin{array}{l}\text { VT1 -0 } \\
\text { employees }\end{array}$ & 166,035 & 40 & 7 & 17 & 36 & 1,164 & 193 & $\mathbf{1 6 7 , 4 9 2}$ \\
\hline $\begin{array}{l}\text { VT2-1-4 } \\
\text { employees }\end{array}$ & 99,693 & 220 & 25 & 963 & 1,914 & 4,511 & 1,813 & $\mathbf{1 0 9 , 1 3 9}$ \\
\hline $\begin{array}{l}\text { VT3-5-9 } \\
\text { employees }\end{array}$ & 15,667 & 121 & 41 & 989 & 435 & 1,291 & 558 & $\mathbf{1 9 , 1 0 2}$ \\
\hline
\end{tabular}




\begin{tabular}{|c|c|c|c|c|c|c|c|c|c|}
\hline $\begin{array}{l}\text { VT4 - 10- } \\
24 \text { employ- } \\
\text { ees }\end{array}$ & 1 & 8,868 & 248 & 212 & 2,048 & 377 & 1,074 & 526 & 13,354 \\
\hline $\begin{array}{l}\text { VT5 - } \\
25-49 \\
\text { employees }\end{array}$ & & 2,470 & 187 & 230 & 1,576 & 198 & 632 & 262 & 5,555 \\
\hline $\begin{array}{l}\text { VT6 - } \\
\text { 50-149 } \\
\text { employees }\end{array}$ & & 1,391 & 91 & 269 & 1,034 & 127 & 680 & 272 & 3,864 \\
\hline $\begin{array}{l}\text { VT7 - } \\
\text { 150-249 } \\
\text { employees }\end{array}$ & & 205 & 16 & 65 & 59 & 10 & 200 & 67 & 622 \\
\hline $\begin{array}{l}\text { SMEs } \\
\text { Intermediate } \\
\text { total }\end{array}$ & 1 & 294,329 & 923 & 849 & 6,686 & 3,097 & 9,552 & 3,691 & 319,128 \\
\hline $\begin{array}{l}\text { VT8 - } \\
\text { 250-499 } \\
\text { employees }\end{array}$ & & 103 & 10 & 66 & 39 & 9 & 188 & 62 & 477 \\
\hline $\begin{array}{l}\text { VT9 - } \\
\text { 500-999 } \\
\text { employees }\end{array}$ & & 35 & 12 & 34 & 14 & 4 & 93 & 37 & 229 \\
\hline $\begin{array}{l}\text { VT10 } \\
-1,000- \\
1,999 \text { empl. }\end{array}$ & & 13 & 1 & 23 & 2 & 0 & 37 & 20 & 96 \\
\hline $\begin{array}{l}\text { VT11 - } \\
2,000+ \\
\text { empl. }\end{array}$ & & 4 & 0 & 20 & 1 & 0 & 20 & 10 & 55 \\
\hline $\begin{array}{l}\text { Large } \\
\text { enterprises } \\
\text { Intermedi- } \\
\text { ate total }\end{array}$ & & 155 & 23 & 143 & 56 & 13 & 338 & 129 & 857 \\
\hline $\begin{array}{l}\text { Statistical } \\
\text { Sample } \\
\text { Total }\end{array}$ & 1 & 294,484 & 946 & 992 & 6,742 & 3,110 & 9,890 & 3,820 & 319,985 \\
\hline $\begin{array}{l}\text { VT99 } \\
\text {-Unspeci- } \\
\text { fied count }\end{array}$ & & 207,532 & 502 & 16 & 268 & 21,280 & 16,755 & 3,404 & 249,757 \\
\hline Total & 1 & 502,016 & 1,448 & 1,008 & 7,010 & 24,390 & 26,645 & 7,224 & 569,742 \\
\hline
\end{tabular}

DV1 -Int'l Public; DV2 -Private Inland; DV3 -Cooperative; DV4 -State; DV5 -Munic. and Self-Governing; DV6 -Assoc., Polit. Parties, Church; DV7 -Foreign; DV8 -Int'l Private 
Another important element from the ownership type perspective is the share of the combined external ownership, including both foreign and international private types. Putting aside the specific size type VT1 without employees, the numbers follow the general path of the private inland ownership and decrease in absolute terms with the rising size of the companies. However, the importance of this ownership type for the Slovak economy appears in relative terms: combined foreign and international ownerships' share increases with the rising size type and suddenly jumps to over 52\% in the size type VT8 (250-499 employees) from almost $42.9 \%$ in VT7 and $24.6 \%$ in VT6 (both size types representing medium-sized enterprises) and keeps even higher levels in the remaining sub-groups of large enterprises.

One of our goals was to determine the distribution type of businesses in Slovakia. Table 3 below contains the results of goodness of fit tests for distribution models of firm sizes for all enterprises in the Slovak Republic. Two goodness-of-fit tests - Kolmogorov-Smirnov and AndersonDarling - were used to determine whether our empirical data set can be considered as a sample from a given specified probability distributions known from the literature review. The latter is, as we have stated, more sensitive to deviations on the tails. The Kolmogorov-Smirnov test confirmed that the Power and Pareto distributions are adequate models for our empirical data. The more sensitive Anderson-Darling test rejected the null hypothesis that the empirical data are from Power (domain is $<2.5 ; 3043.8>$ ) or Pareto distribution at the significance level of 0.05 . Both tests confirmed good agreement with the Generalized Gamma distribution (the p value for Kolmogorov-Smirnov test is 0.9943).

Tab. 3 - Probability Distributions of the Firm Sizes. Source: own research

\begin{tabular}{|c|c|c|c|c|c|}
\hline \multirow{2}{*}{$\begin{array}{l}\text { Distribu- } \\
\text { tion }\end{array}$} & \multirow{2}{*}{ Parameter Estimation } & \multicolumn{2}{|c|}{$\begin{array}{c}\text { Kolmogorov-Smir- } \\
\text { nov Test }\end{array}$} & \multicolumn{2}{|c|}{$\begin{array}{c}\text { Anderson- Darling } \\
\text { Test }\end{array}$} \\
\hline & & $\begin{array}{l}\text { Test sta- } \\
\text { tistics }\end{array}$ & $\begin{array}{l}\text { Critical } \\
\text { value }\end{array}$ & $\begin{array}{l}\text { Test sta- } \\
\text { tistics }\end{array}$ & $\begin{array}{l}\text { Critical } \\
\text { value }\end{array}$ \\
\hline Lognormal & sigma $=1.0117, \mathrm{mi}=1.4533$ & 0.41791 & 0.40925 & 42.726 & 2.5018 \\
\hline Power & alfa $=0.00448, a=2.5 b=3043.8$ & 0.25553 & 0.40925 & 33.156 & 2.5018 \\
\hline $\begin{array}{l}\text { Pareto } \\
\text { (second } \\
\text { kind) }\end{array}$ & alfa $=1.8795$, beta $=8.1729$ & 0.39444 & 0.40925 & 24.744 & 2.5018 \\
\hline Lévy & sigma $=3.2196$ & 0.45925 & 0.40925 & 5.4072 & 2.5018 \\
\hline $\begin{array}{l}\text { Gener- } \\
\text { alized } \\
\text { Gamma }\end{array}$ & $\begin{array}{l}\mathrm{k}=0.83869, \text { alfa }=1.6614, \\
\text { beta }=643.93, \text { gamma }=128.43\end{array}$ & 0.0455 & 0.40925 & 0.13388 & 2.5018 \\
\hline
\end{tabular}

Note: Significance level alfa $=0.05$

Due to the prevalence of SMEs in the structure of businesses, we paid special attention to their deeper analysis. We found a statistically significant dependence between the ownership type and the size type of SMEs (the value of the test statistic of the Chi-square test for independence is 89.169 and the simulated $\mathrm{p}$ value is 0.0000999$)$. 
Therefore, we were also interested in the probability distribution of SMEs in general as well as according to individual ownership types. All values of the test statistic were below the critical value (Table 4), therefore, the null hypothesis that the probability distribution is of Lévy type cannot be rejected at the significance level of 0.05 . Thus, we found out that the probability distribution of SMEs in general as well as according to individual ownership types has a Lévy distribution. SMEs firm size density functions are presented in Figure 1.

The entrepreneurial structure from the viewpoint of the size type can be unequivocally described only through the probability distribution. As for the SMEs, we determined the Lévy distribution as most suitable. State-owned enterprises have the highest value of the sigma parameter (22.4100). It means that the density function for the firm size is in the case of the state ownership the least skewed, i. e. larger enterprises prevail. Contrary to that, the lowest value is for the ownership type "private inland" (3.0032), meaning that the firm size density function is very skewed, implicating a large number of enterprises with a low employee count. A change of the Lévy distribution parameters in the course of time can indicate alterations in the business structure from the firm size perspective. It can be thus used as an instrument for the policy effects evaluation.

Tab. 4 - Probability Distribution of the General Firm Size of SMEs as well as by Ownership Type. Source: own research

\begin{tabular}{|l|l|l|l|l|l|}
\hline \multirow{2}{*}{ Ownership Type } & \multirow{2}{*}{ Est.* } & \multicolumn{2}{|c|}{ Kolmogorov-Smirnov } & \multicolumn{2}{c|}{ Anderson-Darling } \\
\cline { 3 - 6 } & & Test statistics & Critical value & Test statistics & Critical value \\
\hline $\begin{array}{l}\text { DV2 - Private } \\
\text { Inland }\end{array}$ & 3.0032 & 0.5040 & 0.51926 & 1.1812 & 2.5018 \\
\hline $\begin{array}{l}\text { DV3 - Coopera- } \\
\text { tive }\end{array}$ & 7.0122 & 0.21551 & 0.51926 & 0.25625 & 2.5018 \\
\hline DV4 - State & 22.4100 & 0.28771 & 0.51926 & 1.3075 & 2.5018 \\
\hline $\begin{array}{l}\text { DV5 - Munic./ } \\
\text { Self-Governing }\end{array}$ & 9.2390 & 0.23412 & 0.51926 & 0.20833 & 2.5018 \\
\hline $\begin{array}{l}\text { DV6 - Assoc./ } \\
\text { Pol. Part./ Church }\end{array}$ & 3.5734 & 0.39342 & 0.51926 & 0.91606 & 2.5018 \\
\hline DV7 - Foreign & 4.0387 & 0.33407 & 0.51926 & 0.74977 & 2.5018 \\
\hline $\begin{array}{l}\text { DV8 - Int'l. } \\
\text { Private }\end{array}$ & 4.1347 & 0.31987 & 0.51926 & 0.71991 & 2.5018 \\
\hline $\begin{array}{l}\text { All Ownership } \\
\text { Types }\end{array}$ & 3.2016 & 0.46197 & 0.51926 & 1.0799 & 2.5018 \\
\hline
\end{tabular}

* Estimation of the parameter sigma for Lévy distribution 


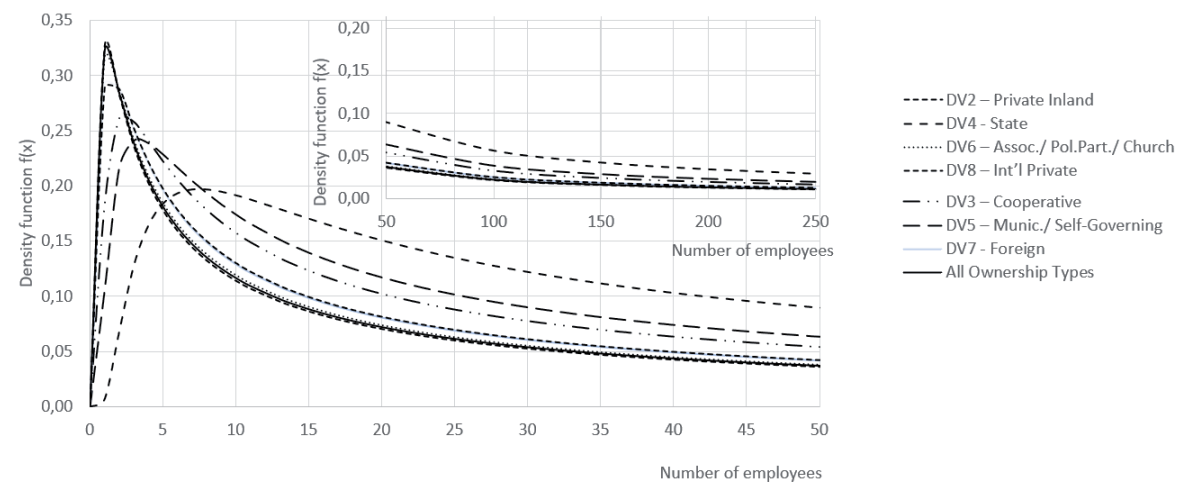

Fig.1 - Density Functions of the Firm Size of SMEs. Source: own research

\section{DISCUSSION}

The following discussion comparing our results to those of other relevant studies should be regarded as strictly selective and quite general. As in the work of most authors, we have tested a variety of probability distributions which produced a rather wide spectrum of results which thus do not offer a single and unambiguous answer for the whole empirical dataset. This along with space limitations prevent us from including all the quoted studies in the overview.

The analysis of firm size distribution is not uncommon, although we are not aware of a study such as ours that is limited to Slovak companies. Many other nationally and regionally focused studies have been published. Further, as already stated by Montebruno et al. (2019), almost every geographical context has been covered. The study of lognormal firm size distribution goes back to Gibrat (1931), who basically started this type of research with his study of French companies. Similar outcomes have been achieved over the following century, e. g. by Hart \& Prais (1956) using a sample of companies in the United Kingdom. Power rules and distributions have been a matter of research, e. g. by Gabaix $(2009,2016)$ and even more recently by Zou (2019) with a study focusing on Chinese companies. Görg et al. (2017) approximated an industry's firm size distribution using the Pareto distribution on a large statistical sample, covering industries in three countries - Germany, Sweden and the UK. The latter country has been studied by Coad (2010) as well.

As stated by Halvarsson (2013), recent applied research shows that firm size distribution tends to conform to a particular power law known as Zipf's law, which has been demonstrated with an extensive dataset of US firms (Axtell, 2001) as well as Japanese companies (Okuyama et al., 1999). Halvarsson (2013) himself has not rejected this hypothesis in his study using a dataset of Swedish companies in the quoted research.

Considering the general type of the firm size distribution, if we relied solely on the broadly applied Kolmogorov-Smirnov test, our results would either be in line with other country-related studies presenting the power and Pareto distributions, or would challenge the original norm 
of the lognormal distribution (going back to Simon \& Bonini, 1958 and more recently others including the afore-mentioned Axtell, 2001, 2006; Coad, 2010; Geerolf, 2017; Torsten \& Shuanping, 2016; Zou, 2019 and others). However, as the Kolmogorov-Smirnov is known to be somewhat unreliable in many cases (Engmann \& Cousineau, 2011), we used the more sensitive Anderson-Darling test, which has not confirmed these kinds of size distributions. Both tests combined showed that the Generalized Gamma distribution is the most fitting to our dataset. Nevertheless, the Generalized Gamma distribution may be under certain conditions approximated with the lognormal distribution (Bell, 1988).

With regard to a regional comparison and the region of Central Europe in particular, we found out that, contrary to Lyócsa \& Výrost (2018) - who tested firm size distribution in 10 emerging economies and revealed that power-law firm size distributions are plausible at the country and industry levels in most CEE countries including Slovakia, whereas the lognormal distribution fitted their data even better (also for Slovakia) - our results were different, with Generalized Gamma as the best fitting distribution for the Slovak empirical dataset after applying the Anderson-Darling test, which is more sensitive to heavy tails. Applying only the Kolmogorov-Smirnov test, we rejected the lognormal distribution; however, power and Pareto were both plausible. From the perspective of methodology, we are thus partially in agreement with the results of Lyócsa \& Výrost: the Kolmogorov-Smirnov test has not rejected the power firm size distribution in both cases. On the other hand, we analyzed a different dataset, one: a) taken from a different year (Lyócsa \& Výrost, 2018); b) different in composition and size. Our dataset was composed of almost 320 thousand companies encompassing all firms about which the Statistical Office had data on employment, i. e. a set almost three times larger than theirs, accounting for a sample of around 113 thousand firms. Even after abstracting from the latter, we may argue that the different results of probability distributions indicate structural changes between 2015 and 2018 in the pool of Slovak firms, which is a representative enough difference to project possible changes in the whole structural mechanism of Slovak companies. Besides its narrow focus on one country, these variances in research findings based on the nature of our study forms the most important limitation of this paper. A deeper analysis of the factors causing these results will be the focus of further research.

\section{CONCLUSION}

As is usual in most if not all economies, the most numerous business size types in the Slovak economy consist of small and medium-sized enterprises, with large enterprises well below $1 \%$. Taking into account the kind of ownership, a dominating number of companies are in private inland (i. e. domestic) ownership, the size structure of which follows the tendency of indirect correlation between the size type based on number of employees and the amount in the respective size type group, both in absolute as well as in relative terms. On the other hand, state ownership follows a sort of direct correlation - the larger the company size, the larger the number of stateowned enterprises up to a certain size level, beyond which the significance rises in relative terms. The importance of the foreign and international private ownership for the Slovak economy is relative as well, with the combined share increasing with the rising size type. 
With respect to the prevailing tendency to use the Kolmogorov-Smirnov test, the empirical data follows the power or Pareto distributions; in addition, this is usual in most studies focusing on size distribution. When combining this with the application of the more sensitive AndersonDarling test, the authors determined that the Generalized Gamma distribution fits best to our dataset. Particular attention was devoted to SMEs in the course of our research, as they form 99.9\% of all business entities in Slovakia. The structure of SMEs from the size perspective can be clearly described through the identification of their probability size distribution. A change in the probability size distribution, as well as an eventual significant change of parameters of the same probability size distribution, can be an indicator of the change in the SMEs structure. This may be used in order to evaluate i. a. policy effects and efficiency, creating a more precise reaction to changes in the macroeconomic environment (e. g. an economic crisis) as well as more accurate estimates of changes of indicators that are dependent on SME size (e. g. productivity, profitability). As stated by for example Görg et al. (2017), firm-size distribution is an important determinant in the relationship between an industry's employment and output.

Our original research results have been achieved with regards to the effects of ownership on the firm size distribution using, in our case, a large empirical dataset of SMEs for which a statistically significant dependence was identified between ownership type and size type. We were also interested in probability distributions according to ownership type. We found out that the probability distribution of SMEs in general as well as according to individual ownership types showed a Lévy distribution.

Only the density function fully describes a continuous random variable. We consider the identification of the probability distribution of the number of enterprises according to the size type or type of ownership to be important and scientifically significant. The very shape of the size distribution of companies can indicate other characteristics of companies. Therefore, any economic considerations analyzing the impact of policies, responses to shocks or regional development on the basis of average number, describing a standard deviation in relation to the number of enterprises of a certain size or type of ownership may be misleading. Following this premise, it is clear that it cannot be concluded that if the average size and the standard deviation have not changed, neither has the structure changed in terms of firm size or ownership. On the contrary, a change in the probability distribution, i.e. a significant change in parameters in the case of individual ownership types, may clearly indicate a substantial alteration in the structure of the particular ownership. This itself provides a justifiable motive for an examination of forces causing these alterations.

\section{Acknowledgement}

This research was funded by GA AA scientific grant No. GA/7/2019 "Analysis of the business structure in Slovak regions."

\section{References}

1. Ahsanullah, M., \& Nevzorov, V. B. (2019). On Some Characterizations of the Lévy

Distribution. Stochastics and Quality Control, 34 (1), 53-57.

https://doi.org/10.1515/eqc-2018-0031 
2. An, H. J., \& Kim, W. K. (2019). A Case Study on the Influence Factors of Financial Performance of Korean Automotive Parts Cooperation Companies through Research Hypothesis. The Journal of Asian Finance, Economics and Business, 6 (3), 327-337. https://doi.org/10.13106/jafeb.2019.vol6.no3.327

3. Angelini, P., \& Generale, A. (2008). On the Evolution of Firm Size Distributions. American Economic Review, 98 (1), 426-438. https://doi.org/10.1257/aer.98.1.426

4. Axtell, R. L. (2001). Zipf Distribution of U.S. Firm Sizes. Science, 293, 1818-1820. https://doi.org/10.1126/science.1062081

5. Axtell, R. L. (2006). Firm Sizes: Facts, Formulae, Fables and Fantasies. CSED Working Paper Series No. 44. Washington: The Brookings Institution.

6. Babutsidze, Z. (2016). Innovation, competition and firm size distribution on fragmented markets. Journal of Evolutionary Economics, 26 (1), 143-169. https://doi.org/10.1007/s00191-015-0425-5

7. Bell, B. M. (1988). Generalized gamma parameter estimation and moment evaluation. Communications in Statistics - Theory and Methods, 17 (2), 507-517. https://doi.org/10.1080/03610928808829637

8. Bottazzi, G., Pirino, D., \& Tamagni, F. (2015). Zipf law and the firm size distribution: a critical discussion of popular estimators. Journal of Evolutionary Economics, 25 (3), 585-610. https://doi.org/10.1007/s00191-015-0395-7

9. Bryson, M. C. (1974). Heavy-Tailed Distributions: Properties and Tests. Technometrics, 16 (1), 61-68, https://doi.org/10.1080/00401706.1974.10489150

10. Coad, A. (2010). The Exponential Age Distribution and the Pareto Firm Size Distribution. Journal of Industry, Competition and Trade, 10 (3-4), 389-395. https://doi.org/10.1007/s10842-010-0071-4

11. Engmann, S., \& Cousineau, D. (2011). Comparing distributions: the two-sample AndersonDarling test as an alternative to the Kolmogorov-Smirnoff test. Journal of Applied Quantitative Methods, 6 (3), 1-17.

12. Gabaix, X. (2009). Power Laws in Economics and Finance. Annual Review of Economics, 1, 255-293. https://doi.org/10.1146/annurev.economics.050708.142940

13. Gabaix, X. (2011). The Granular Origins of Aggregate Fluctuations. Econometrica, 79 (3), 733-772. https://doi.org/10.3982/ecta8769

14. Gabaix, X. (2016). Power Laws in Economics: An Introduction. Journal of Economic Perspectives, 30 (1), 185-206. https://doi.org/10.1257/jep.30.1.185

15. Gaffeo, E., Di Guilmi, C., Gallegati, M., \& Russo, A. (2012). On the mean/variance relationship of the firm size distribution: Evidence and some theory. Ecological Complexity, 11, 109-117. https://doi.org/10.1016/j.ecocom.2012.05.001

16. Garicano, L., Lelarge, C., \& Van Reenen, J. (2016). Firm Size Distortions and the Productivity Distribution: Evidence from France. American Economic Review, 106 (11), 3439-3479. http://dx.doi.org/10.1257/aer.20130232 
17. Geerolf, F. (2017). A Theory of Pareto Distributions. UCLA Working Paper. Retrieved March 31, 2020 from: https://fgeerolf.com/pareto.pdf

18. Gibrat, R. (1931). Les inégalités économiques. Paris: Sirey

19. Görg, H., Henze, P., Jienwatcharamongkhol, V., Kopasker, D., Molana, H., Montagna, C., \& Sjöholm, F. (2017). Firm size distribution and employment fluctuations: Theory and evidence. Research in Economics, 71 (4), 690-703. https://doi.org/10.1016/j.rie.2017.09.002

20. Gourio, F., \& Roys, N. (2014). Size-dependent Regulations, Firm Size Distribution and Reallocation. Quantitative Economics, 5 (2), 377-416. https://doi.org/10.3982/qe338

21. Halvarsson, D. (2013). Industry Differences in the Firm Size Distribution, Ratio Working Paper No. 214, Stockholm: The Ratio Institute, Sweden 2013. http://ratio.se/app/ uploads/2014/11/industry_diffrences_in_the_firm_size_distribution_wp214.pdf

22. Hart, P. E., \& Prais, S. J. (1956). The Analysis of Business Concentration: A Statistical Approach. Journal of the Royal Statistical Society, 119 (2), 150-191. http://dx.doi.org/10.2307/2342882

23. Kondo I. O., Lewis, L. T., \& Stella, A. (2018). On the U.S. Firm and Establishment Size Distributions. Finance and Economics Discussion Series, 2018-075. Washington: Board of Governors of the Federal Reserve System. https://doi.org/10.17016/feds.2018.075

24. Link, A. N., \& Scott, J. T. (2018). Propensity to Patent and Firm Size for Small R\&D-Intensive Firms. Review of Industrial Organization, 52 (4), 561-587.

https://doi.org/10.1007/s11151-018-9617-0

25. Luttmer, E.G. J. (2007). Selection, Growth, and the Size Distribution of Firms. The Quarterly Journal of Economics. 122 (3), 1103-1144. https://doi.org/10.1162/qjec.122.3.1103

26. Lyócsa, Š., \& Výrost, T. (2018). Scale-free Distribution of Firm-size Distribution in Emerging Economies. Physica A: Statistical Mechanics and its Applications, 508, 501-505. https://doi.org/10.1016/j.physa.2018.05.088

27. Matijek, P. (2018). 50 firiem tvorí 60 percent HDP Slovenska. To je rebríček Forbes Top 50. Forbes. https://www.forbes.sk/50-firiem-60-percent-hdp-slovenska-to-je-rebricek-forbestop-50/

28. Meisenzahl, R. R. (2016). Can Financing Constraints Explain the Evolution of the Firm Size Distribution? Review of Industrial Organization, 48 (2), 123-147. https://doi.org/10.1007/s11151-015-9498-4

29. Montebruno, P., Bennet, R. J., van Lieshout, C., \& Smith, H. (2019). A Tale of Two Tales: Do Power Law and Lognormal Models fit Firm-size Distributions in the Mid-Victorian Era? Physica A: Statistical Mechanics and Its Applications, 523, 858-875. https://doi.org/10.1016/j.physa.2019.02.054

30. Ministry of Economy (2017). Tretia monitorovacia správa o plnení cielov Stratégie vonkajších ekonomických vzt’ahov SR na obdobie 2014-2020. Hodnotiace obdobie rok 2016. Bratislava: Ministerstvo hospodárstva Slovenskej republiky.

31. Ministry of Economy (2020). Štvrtá monitorovacia správa o plnení cielov Stratégie vonkajších ekonomických vzt’ahov SR na obdobie 2014-2020. Hodnotiace obdobie rok 2018. Bratislava: Ministerstvo hospodárstva Slovenskej republiky. 
32. Okuyama, K., Takayasu, M., \& Takayasu, H. (1999). Zipf's law in income distribution of companies. Physica A: Statistical Mechanics and its Applications, 269 (1), 125-131.

https://doi.org/10.1016/S0378-4371(99)00086-2

33. Pascoal, R., Augusto, M., \& Monteiro, A. M. (2016). Size distribution of Portuguese firms between 2006 and 2012. Physica A: Statistical Mechanics and Its Applications, 458, 342-355. https://doi.org/10.1016/j.physa.2016.04.010

34. Peng, G. H., \& Xia, F. (2016). The size distribution of exporting and non-exporting firms in a panel of Chinese provinces. Papers in Regional Science, 95, 71-86. https://doi.org/10.1111/pirs.12119

35. Poschke, M. (2018). The Firm Size Distribution across Countries and Skill-Biased Change in Entrepreneurial Technology. American Economic Journal: Macroeconomics, 10 (3), 1-41. https://doi.org/10.1257/mac.20140181

36. Rimmer, R. H., \& Nolan, J. P. (2005). Stable Distributions in Mathematica. The Mathematica Journal, 9 (4), 776-789. https://www.researchgate.net/profile/John_Nolan4/ publication/242740619_Stable_Distributions_in_Mathematica_Robert_H_Rimmer/ links/542950e20cf2e4ce940c9dc6/Stable-Distributions-in-Mathematica-Robert-H-Rimmer. pdf

37. Rosenthal, J. A. (2011). Statistics and data interpretation for social work. Springer.

38. Rotundo, G., \& Scozzari, A. (2009). Co-evolutive models for firms dynamics. In Naimzada, A. K., Stefani, S., \& Torriero, A. Networks, topology and dynamics. Theory and Applications to Economic and Social Systems. Heidelberg: Springer.

39. Santarelli, E., Klomp, L., \& Thurik, A. R. (2006). Gibrat's Law: An Overview of the Empirical Literature. In Santarelli, E. (Ed.). Entrepreneurship, Growth, and Innovation. International Studies in Entrepreneurship, Vol. 12, Boston: Springer.

40. SBA (2019a). Malé a stredné podnikanie v číslach v roku 2018. Bratislava: Slovak Business Agency. http://www.sbagency.sk/sites/default/files/msp_v_cislach_2018.pdf

41. SBA (2019b). Správa o stave malého a stredného podnikania v Slovenskej republike v roku 2018. Bratislava: Slovak Business Agency. http://www.sbagency.sk/sites/default/files/ sprava_o_stave_msp_2018_aktualizovane.pdf

42. Simon, H. A., \& Bonini, Ch. P. (1958). The Size Distribution of Business Firms. American Economic Review, 48 (4), 607-617. http://digitalcollections.library.cmu.edu/awweb/ awarchive?type $=$ file $\&$ item $=39431$

43. Stam, E. (2010). Growth beyond Gibrat: firm growth processes and strategies. Small Business Economics, 35(2), 129-135. https://doi.org/10.1007/s11187-010-9294-3

44. Sutton, J. (1997). Gibrat's Legacy. Journal of Economic Literature, 35 (1), 40-59. http://darp.lse.ac.uk/PapersDB/Sutton_(JEL97).pdf

45. Torsten, H., \& Shuanping, D. (2016). Diversity of firm sizes, complexity, and industry structure in the Chinese economy. Structural Change in Economic Dynamics, 37, 90-106. https://doi.org/10.1016/j.strueco.2016.01.001 
46. Trang, P. T. H., \& Nam, V. H. (2020). Distance to the Frontier and Innovation: The Role of the Local Business Environment. Malaysian Journal of Economic Studies, 57 (1), 21-37.

https://doi.org/10.22452/MJES.vol57no1.2

47. Viner, J. (1932). Cost Curves and Supply Curves. Zeitschrift für Nationalökonomie, 3 (1), 23-46. https://doi.org/10.1007/bf01316299

48. Wolfram (2020). Wolfram Language \& System Heavy Tail Distributions. https://reference. wolframcloud.com/language/guide/HeavyTailDistributions.html

49. Yuan, Q. G., Zhao, Y. P., Shang, H., Zhang, W., \& Umar, Z. (2016). Financing constraints on the size distribution of industrial firms: the Chinese experience. Applied Economics, 48 (41), 3899-3911. https://doi.org/10.1080/00036846.2016.1148256

50. Zou, Y. J. (2019). An analysis of Chinese firm size distribution and growth rate. Physica A: Statistical Mechanics and its Applications, 535, 122344. https://doi.org/10.1016/j.physa.2019.122344

\section{Contact information}

Ing. Marek Csabay, PhD.

Pan-European University

Faculty of Economics and Business

Slovakia

E-mail:marek.csabay@paneurouni.com

ORCID: 0000-0001-6693-7750

prof. RNDr. Beata Steblikova, CSc.

Pan-European University

Faculty of Economics and Business

Slovakia

E-mail:beata.steblikova@paneurouni.com

ORCID: 0000-0003-1064-6254 